\title{
PEDAGOGY
}

\section{THE DEVELOPMENT OF STUDENTS' CRITICAL THINKING IN LEARNING A FOREIGN LANGUAGE}

\author{
Master of Humanities Suleimenova Zh. A., \\ Master of Philology Kalikhaidarova G. E., \\ Master of Humaties Mussabekova Z. S., \\ Master of Pedagoics Duishonaliyeva B. T. \\ Eurasian National University after L.N. Gumilyev, Nur-Sultan, Kazakhstan
}

DOI: https://doi.org/10.31435/rsglobal_wos/30112019/6808

\section{ARTICLE INFO}

Received: 11 September 2019

Accepted: 14 November 2019

Published: 30 November 2019

\section{KEYWORDS}

critical thinking,

critical thinking skills,

role plays,

active reading,

Socratic Questioning.

\begin{abstract}
This article deals with the issue of working out and incorporating in educational process of higher educational institutions of the innovative technology for developing skills of critical thinking for the future Management specialists. The research is aimed at revealing both theoretical and practical ideas about critical thinking development in English language teaching. To enhance critical thinking in learners, foreign language teachers use various methods and techniques, consequently there have been described the following methods such as "Lead-in", "Socratic Questioning", "Business role play", "Active reading", and "Translation". The use of the above methods by foreign language teachers in classes contribute to the development of critical thinking among students and motivate them for learning a foreign language, as well as making the study process be possible to turn from routine work into interactive, interesting and challenging activities.
\end{abstract}

Citation: Suleimenova Zh. A., Kalikhaidarova G. E., Mussabekova Z. S., Duishonaliyeva B. T. (2019) The Development of Students' Critical Thinking in Learning a Foreign Language. International Academy Journal Web of Scholar. 11(41), Vol.2. doi: 10.31435/rsglobal_wos/30112019/6808

Copyright: (C) 2019 Suleimenova Zh. A., Kalikhaidarova G. E., Mussabekova Z. S., Duishonaliyeva B. T. This is an open-access article distributed under the terms of the Creative Commons Attribution License (CC BY). The use, distribution or reproduction in other forums is permitted, provided the original author(s) or licensor are credited and that the original publication in this journal is cited, in accordance with accepted academic practice. No use, distribution or reproduction is permitted which does not comply with these terms.

Nowadays it is crucial to use various non-traditional methods and techniques in order to learn a foreign language in higher educational institutions. One of these ways is critical thinking. As H. Oliver and R. Utermohlen claimed, students need to develop and effectively apply critical thinking skills to their academic studies, to the complex problems that they will face, and to the critical choices they will be forced to make as a result of the information explosion and other rapid technological changes [1].

The intellectual roots of critical thinking trace back etymologically 2,500 years ago to the teaching practice and vision of Socrates who discovered by methods of probing questioning that people could not rationally justify their confident claims to knowledge. Socrates demonstrated that person may have power and high position and yet be deeply confused and irrational. He established the importance of seeking evidence, closely examining reasoning and assumptions, analyzing basic concepts, and tracing out implications not only of what is said but of what is done as well. His method of questioning is now known as "Socratic Questioning" and is the best known critical thinking teaching strategy.

"Critical thinking" means accepting any ideas, understanding, studying why it applies, and expressing opposing views on these ideas. That is, each student shows interest in classes, freely expresses his thoughts, draws conclusions, analyzes performances, argues his thought, makes joint creative work.

One of the most famous models describing the process of thinking formation is Taxonomy by B. Bloom, which is a hierarchical order of cognitive skills that many teachers use for lesson planning, curriculum development, personalization and differentiation of learning, assessment of the complexity 
of tasks, development of online courses, etc. The purpose of this system is to encourage the development of such forms of thinking as the analysis and evaluation of concepts, processes, procedures and principles, and not just memorizing facts. In Bloom's point of view, learning objectives directly depend on the hierarchy of thought processes from the most basic to the most advanced: Knowledge - Comprehension - Application - Analysis - Synthesis - Evaluation [2].

In 2001 the scientists L. Anderson and D. Krathwohl suggested their own variant of assessment scale and made some changes in Bloom's Taxomony. There have been put the following tasks: Remember - Understand - Apply - Analyze - Evaluate - Create [3]. The exercises assigned by the teachers in accordance with the Taxomony of L. Anderson and D. Krathwohl develop critical thinking, contribute to active learning and allow students to practice different levels of cognitive spheres.

It should be noted that successful, qualified professionals need to learn critical thinking. It is necessary for foreign language learners to understand any opinion correctly and be prepared to analyze relevant information. A person who is able to think critically, on the basis of his views forms the world view, identifying materials derived from various informational data. The future specialist, thinking in a critical form, uses this knowledge in negative situations. Critical thinking is required for everyone to analyze the information obtained from the media, Internet networks. Comparing data from various sources of information, a person with well-developed critical thinking easily finds inconsistent errors and explains solutions with arguments. In addition, he connects the opposite point of view with each other and on the basis of it forms his position.

Many scientists have expressed their opinions on the problem of defining critical thinking. D. Halpern explains "critical thinking" as the application of cognitive skills and strategies that increase the likelihood of obtaining the necessary results. In his opinion, in order to be able to think critically, it is necessary for students to develop the following qualities:

1. Be ready for planning. Opinions are usually inaccurate. Therefore, as the statement of opinion, it should be consistently compiled.

2. Flexibility. If a student never perceives the opinions of others, then he cannot convey his thoughts.

3. Modest. If we are faced with a difficult situation, we leave it for later. The student must achieve many good results, developing his dedication and courage in a smart tension.

4. Willingness to correct your mistakes. A critical thinker never believes in his wrong decisions, he seeks to make a positive decision, applying mistakes in the process of further learning.

5. Careful understanding. These are the most basic qualities. The student must control and check himself in the process of thinking.

6. Search for the optimal solution. The decision made by the student must be hold by other students, otherwise it goes unnoticed as a merely agreed word $[4,22]$.

D. Kloster gives five different characteristics of critical thinking as follows:

1. Critical thinking is independent personal thinking

2. Information is the starting point of critical thinking

3. Critical thinking asks the question, the problem begins with the definition

4. Critical thinking tends to confident arguments.

5. Critical thinking-social thinking [5].

Taking into consideration the opinions of these scientists, critical thinking can be defined as a complex process of thinking, starting with the reception of information and ending with a reasonably thought-out independent decision. That is, it is systematically explained as follows:

1) receiving information;

2) asking questions;

3) comparing data from various information sources;

4) systematic examination of judgments;

5) making decisions.

Methodology. It is the responsibility of teachers and educators to understand the components of the set of skills and focus on them in order to guarantee effective education. Critical thinking skills should be given priority as they create a meaningful learning process and help students to succeed in an academic environment and everyday life. Currently, the method of "critical thinking" is widely used in the teaching a foreign language as students express their opinions, make decisions, cooperate with the group. When learning a foreign language, traditional teaching methods are not enough. Only with the help of speech and written exercises it is difficult to teach students the language. But how to teach students a foreign language using "critical thinking"? 
As it has been stated above, citical thinking technique is an effective way to improve the quality of education. Classes held in the framework of the program of this approach are very convenient for students to complete mastering the topic and performing independent work. The use of this methodology is the basis for the development of individual thinking, aesthetic education, development of communication skills, making optimal decisions, and foremost to improve the quality of education.

This methodology consists of three structures, in particular, the phases as "realization, understanding, and reflection" [6].

1. Phase of implementation. At this stage, the teacher is trying to awaken the interest of the student to a new topic. All students work together to achieve their goals. Able to systematize information on a new topic, freely express their thoughts. Let the ideas expressed be correct, erroneous, whereas the teacher must listen to everyone. At this stage it is necessary to understand that "any opinion of the student" matters.

For example, students ask each other questions on a new topic. Then he answers questions, discusses opinion. Even if there are grammatical errors, the teacher does not attach much importance to it. In addition, when reading texts, find the key words, make sentences from them and give under headings for each paragraph.

2. Phase of understanding. At this stage, a student who has received new information is trying to change his sentences. If in the "implementation phase" students identify their cognitive directions, they understand the questions posed in the "understanding phase" and try to give them the right answers. The tasks that will be given at this stage will be different. That is, group or individual work will be done (discussion, dialogue, conversation, reading or watching video materials). But in this case, students try to understand the information themselves and actively participate in classes.

For example, on studying a new topic, students read the text, stop after each paragraph and ask questions to each other. This type of task enhances their communicative competence.

3. Phase of reflection. At this stage, students reflect and provide an opportunity to create a new topic. That is, the new topic becomes their peculiar knowledge, and the activity between the student and the teacher becomes the main task. If the opinion of one student requires discussion, then the opinion of another student depends on the topic. This stage develops the ability of the student to critical thinking. The main exercises of this stage are: organizing a round table, performing creative works, protecting projects. For example, the protection of projects is the basis for the formation of the student's personality. When completing a project protection, attention should be paid to the following requirements:

- a significant or controversial problem in the research project;

- the practical and theoretical significance of the intended results;

- extracurricular work of students;

- materiality of the main part of the project;

Situation. The problem of critical thinking in learning a foreign language has not been studied enough methodologically. Therefore, the teacher should independently develop the necessary didactic and methodological materials.

Typically, various pedagogical methodology that meet modern requirements can serve as a basis for the development of a teacher's creative abilities. However, the teacher will know which of these methods should be put into practice. In this regard, when teaching a foreign language to students, teachers of use various methods aimed at the development of critical thinking. The most commonly used techniques are:

- introduction to the topic (Lead-in);

- Socratic questioning method;

- graphical representation of information in the form of tables, graphs and Mind-maps;

- presentations;

- role-playing games;

- reading (Active Reading, Dipping into and Skimming);

- translations (translation from a foreign language into native language and from native language into a foreign language)

Here we consider some of the methods.

Topic introduction (Lead-in) "warm up students" - tended to arouse interest in a new topic by referring the student to previous experience or knowledge that is relevant or related to the new topic. The role of the teacher is to encourage students to use background knowledge on the topic, conflictfree exchange of views in groups, systematization of information received from students. It is important not to criticize the answers, as any opinion is valuable. In this regard, in the classroom, 
students should be given the opportunity to express their point of view about the topic studied freely, without fear of making mistakes and being corrected by the teacher, to make decisions independently. It is also important to understand that critical thinking does not have to be completely original, students have the right to accept the idea or beliefs of another person as their own. Thus, the existing knowledge and experience of students can be used to personalize the lesson, thereby awakening students' interest in the discussed material, because thinking can be critical only when it is of an individual nature. As an assignment, students can be offered the following [7]:

1. make a list of known information;

2. story-assumption by keywords;

3. confused logic chains;

4. true and false statements;

5. systematization of the material graphically;

6. to answer open-ended questions;

7. compare and justify your point of view.

When using the method of "Active reading" the teacher makes such tasks which require students careful and purposeful reading of the text to the end, finding answers to the teacher's questions, extracting and interpreting specific information, identifying its importance, also finding out and assessing the consequences of the taken solution to the problem, the latter having sound arguments for the own position, and surely the logic comprehension of the opponents' arguments, comparing them with the facts and evaluation of counterarguments. Consequently, the teachers of the department think of pre-text and post-text tasks that contribute to the development of students not only critical, but also analytical and logical thinking.

Types of exercises:

1. Make reasonable comments on the following sentences;

2. Answer the following questions, discuss with your partner your answers' objectivity;

3. Discuss the following statements in the group. Which statements do you agree with and which do not? Why?

4. Read the following sentences and name which sentences do not match the information in the text;

5. Fill in the intelligence card and state its contents;

6. State the main facts, put forward your ideas and prove;

7. Make a short report on a given topic based on the information from the text,

Role-playing games. The use of role playing during classes is a method of effective learning, as it removes the contradictions between the abstract nature of the subject and the real nature of professional activity and contributes to the solution of such problems as learning the new educational material, the consolidation of vocabulary, the development of creative abilities of students. Role play games have a flexible structure and can be based on cases, letters (requests, responses, complaints, invitations, etc.) and descriptions of different situations for both parties. In addition, role play games give students the opportunity to develop the competencies that are necessary for their chosen profession. The role play game is composed using appropriate speech material and includes a range of methods of active learning: discussion, brainstorming, analysis of specific production situations $[8, \mathrm{p}$. 45-48]. The introduction of a role play game into the university pedagogical process, as linguists state, contributes to the formation of the professional development of the personality as a specialist [9].

The secret of success in role play games lies in their ability to present real problems, based on real speech material reflecting the specific situation of communication in the professional sphere and to practice knowledge and skills immediately, as the students are provided with a safe environment for plunging into corporate problems that arise in real companies. Another key aspect of business games is interactive learning. Role play games increase the motivation of students, as in the course of the game learning becomes personal and acquires an emotional context. Different researches show that our brains remember knowledge better if we actively participate or interact in learning it. In addition, business games expand knowledge about intercultural differences, as they train during the game patterns of behavior in specific situations with the "participation" of foreign partners. And students are sure to understand and remember language models better, as the business game provides an opportunity for practical application of a foreign language.

Topics for business games for the students studying the specialty "Management" are very diverse and interesting. For example: Recruitment, Marketing mix and Market Research, Marketing Promotions, Advertising, organization of Events and Exhibitions, etc. For example, to consolidate the theme "Marketing a new brand", the teacher divides students into two teams: 1) representatives of the 
PR Agency and 2) representatives of the company that applied to the Agency for help in promoting a new brand on the market. The first group students are given a summary of the new brand, the country where the client company is going to present the new brand, data on market research, and cultural characteristics of the country. The second group students are given a summary of the new brand and the company they represent. The students are given a little time to read and prepare for the roleplaying game. Thus, students have the opportunity to apply their knowledge and language models on the topics of "Marketing", "Marketing mix", "market research" and "Intercultural communication" and behave as professionally as possible, pretending to be employees of these companies.

Socratic Questioning is an effective way of teaching critical thinking and a useful tool for a teacher. Critical thinking begins with asking questions and understanding the problem. Questions formulated correctly and used during the class, make the students feel comfortable and participate in learning the given material, moreover they are used by the teacher in the following processes as reflection, debate, discussion, evaluation and analysis of the content of material. Questions contribute to a deeper understanding of the studied material, assimilation of information. The method of Socrates can be used both to consolidate the material passed, and to study new information. Questions are usually prepared by the teacher in advance, although, as practice shows, new questions can be proposed to students, based on their answers to pre-prepared questions of the teacher. For example:

1 . Which of the press releases is the best and why?

2. Can you analyze the approaches in the PR campaign _ _ _(any company name) with PEST and SWOT analysis in mind?

3. What makes this PR activity not ethical? Can you give an example of an ethical PR campaign?

4. Why did this PR campaign fail?

5. Why are you sure that SWOT analysis in this situation can be useful?

6 . What makes this brand unique?

Translation method. The main purpose of studying a foreign language in a non-linguistic University is to prepare students for speech interaction in professional, business and socio-cultural spheres of intercultural oral and written communication. The ultimate goal of training students is the practical development of a foreign language at a level sufficient for the implementation of intercultural communication in the professional sphere. When studying a foreign language, the student should not compare it with his native language, but accept the cultural differences and distinctive features of the ways of verbal expression. The task of the teacher is to teach students not only to understand the language, but also the culture, customs, way of life of the people of the country of the studied language, since the language is not separable from culture and culture imposes its distinctive features on the vocabulary, grammatical structure of the language, etc. Practicing the technique of critical thinking while trying to identify similarities and differences in how the same language cliché is expressed in words in another language makes the learning process more interesting and culturally enriching.

Taking into account the informational richness of texts related to the specialty "Management", difficult terms, different grammatical structures, absent in the native language, translation from a foreign language into native and from native into foreign language provides a better understanding of language and cultural differences. The following tasks perform several functions:

1. contribute to a better understanding of new information;

2. develop analytical and logical thinking;

3. activate the intellectual activity of the student, accelerates the process of assimilation of new material and enriches the vocabulary.

In order to extract new information on the topic under study, you can give an optional translation of the text and the task to it. For example: "Read an excerpt from the text without a dictionary, determine whether the text contains any new information. If so, discuss it with your partner. Add new information to your intelligence map. Translate the text into your native language."

All students participating in the critical thinking process acquire the skills of independent work. This will serve as the basis for their independent development, formation. Working in groups, students learn responsibility, communication, patience, and politeness. These qualities contribute to the education of students.

As a result of critical thinking, students will have the following opportunities:

1. Ability to work with others;

2. Responsible attitude to their education;

3. Improving the efficiency of receiving information; 
4. The manifestation of interest in the ongoing topics, the learning process in general

5. Adoption of any unexpected ideas and opinions;

6. Do not turn the negative moments into wrinkles

7. The development of self-confidence and the understanding that every opinion is valuable;

8. Listening to different opinions polite;

9. Application of new words and phrases on the topic in their formulations;

Instructors must fulfill the following requirements:

1. Adoption of any unexpected ideas and opinions;

2. Support for the active activities of students in learning;

3. Require credible, credible criticism of each student;

4. Creating conditions for independent development;

5. Changing the preparation for classes;

6. Changing roles in the educational process;

- the teacher inspires students;

-consult;

- controls;

7. Evaluation of critical opinion.

Possessing these a fore mentioned possibilities, the student can freely express his / her opinion to the teacher and freely express his / her opinion. Using this methods, the teacher makes it possible on an ongoing basis to look for work, responsible for classes.

Mukhtarkhanova S., relying on the opinion of Polat, notes that "a student of a post-industrial society" should be a person who can think critically, overcome difficulties, make decisions independently [10]. That is, the teacher must teach a foreign language as a knowledge of the world through a foreign language, choosing the right one, independent search, and raising professional level.

To sum up, theoretical consideration of issues on critical thinking shows the importance of using this innovative approach in classroom activities, it having a great influence on developing critical thinking skills. The following techniques as "Lead-in, "Socratic Questioning", "Business role play". "Active reading", and "Translation" can facilitate the effective developing of critical thinking skills of students. Using these abilities in the process of learning English, we will help increase student interest, deepen knowledge and expand vocabulary. Critical thinking being incorporated in the process of teaching a foreign language not only accelerates the learning process, but also develops the skills to value relationships and motivation for students to achieve. In case of using critical thinking strategies in English classes, students have the opportunity daily to learn the language in accordance with the requirements of life.

\section{REFERENCES}

1. Oliver, H., Utermohlen, R. An Innovative Teaching Strategy: Using Critical Thinking to Give Students a Guide to the Future/ H. Oliver, R. Utermohlen. - Eric Document Reproduction Services № 389702

2. Clark, D. R. 2010. Bloom's Taxonomy of Learning Domains. Retrieved July 10, 2012 from http://www.nwlink.com/ donclark/hrd/bloom.html/.

3. Anderson, L.W., Krathwohl, D.R. Taxomony for learning, teaching, and assessing. New York: Longman, 2001

4. Х Халперн Д. Психология критического мышления // СПб.: Питер, 2000. Б.512.

5. Клустер Д. Что такое критическое мышление // http://rus.1 september.ru/article.php?ID=200202902

6. Наймушина Л.П. Применение технологий развития критического мышления на уроках английского языка // http://nsportal.ru/shkola/inostrannye-yazyki/library/2013/09/24/primenenie-tekhnologii-razvitiya-kriticheskogo

7. Заир-Бек С. И., Муштавинская И. В. Развитие критического мышления на уроке, Москва, Просвещение, 2011 г.

8. Майсейкова В. Е., Сидорова Е. А. Роль деловой игры на уроках английского языка в подготовке выпускников суворовских училищ к выбору будущей профессии [Текст] // Инновационные педагогические технологии: материалы VIII Междунар. науч. конф. (г. Казань, май 2018 г.). — Казань: Молодой ученый, 2018. — C.45-48.

9. Ливингстоун К. Ролевые игры в обучении иностранным языкам. - М., Высшая школа, 1988

10. Мұқтарханова А.М. Жоғары оқу орындарында ағылшын тілін оқытуда сыни ойлауды қалыптастыру // http://repository.enu.kz/ 